\title{
THE OXYGEN DISSOCIATION CURVE IN ANEMIA OF VARIOUS TYPES 1
}

\author{
BY A. C. KENNEDY AND D. J. VALTIS 2
}

(From the University Department of Medicine, The Royal Infirmary, Glasgow)

(Submitted for publication March 1, 1954; accepted June 23, 1954)

It is a clinical observation of long standing that the patient who has become anemic gradually, is often well compensated for the lower hemoglobin level he possesses. Thus it is not uncommon for an individual with a hemoglobin level well below 50 per cent, due to pernicious anemia or hypochromic anemia, to carry on his normal activities. It is generally believed that the compensatory adjustment is in part due to increased utilization of oxygen by the tissues and in part to circulatory adaption. It has also been suggested, from studies of the gas transport of red cells in anemia $(1-4)$, that it may in part be due to displacement of the oxygen dissociation curve to the right of normal whereby the amount of oxygen released to the tissues is increased; the number of patients observed in these investigations is small probably because of the difficulties and time-consuming nature of the methods. The fullest report is that of Richards and Strauss (2) who indicated a shift to the right of the oxygen dissociation curve apparent, however, only at the abnormal plasma $\mathrm{pH}$ of 7.64. Only the reports of Dill and his coworkers (3) and Isac, Matthes, and Yamanaka (4), demonstrate a shift to the right of the oxygen dissociation curve at the standard plasma $\mathrm{pH}$ of 7.4. There are no observations, as far as we are aware, on the oxygen dissociation curve at various stages after recovery from anemia. Many of the patients in these early reports had received whole blood transfusions before the blood gas studies and, as we have shown, this produces an alteration in the oxygen dissociation curve of the anemic recipient (5). Various hypotheses, many of them contradictory, have been offered regarding the cause of the beneficial shift of the oxygen dissocia-

\footnotetext{
1 Much of the cost of apparatus and materials was provided by the Rankin Fund of the University of Glasgow.

2 Enabled to undertake this work by scholarships from the E.C.A. for Greece and from the University of Thessaloniki.
}

tion curve in anemia but none of them affords a satisfactory explanation for the phenomenon.

For these reasons a further and more extensive study of the oxygen dissociation curve in anemia appeared warranted. The present paper describes the oxygen dissociation curves of twenty-nine individuals suffering from various types of anemia. Observations on the position of the oxygen dissociation curves at various times during and after recovery from the anemia are also presented.

\section{MATERIAL AND METHODS}

The subjects of this study comprised eleven patients with megaloblastic anemia in relapse and three in therapeutic remission, three patients with nutritional hypochromic anemia, three patients with hypochromic anemia secondary to chronic hemorrhage, two patients with aplastic anemia, four patients with anemia associated with chronic nephritis, acute leukemia, reticulosis, and scurvy respectively, and three patients with hemolytic anemia. Many of the observations were made before specific therapy was administered and subsequent curves were performed at different periods during and after recovery. None of the patients had received blood transfusions before the blood gas studies were performed, with the exception of one patient with aplastic anemia of long standing (Table II, Case 12).

The collection of blood samples, the equilibration in tonometers with the desired gas tensions, the gas analyses, and the plasma $\mathrm{pH}$ ( $\mathrm{pHs}$ ) determinations were performed on venous blood samples removed without stasis by the methods described elsewhere (5). The subjects were resting for at least one hour before the removal of the blood samples. The cell $\mathrm{pH}(\mathrm{pHc})$ was determined from the Henderson-Hasselbalch equation given below. In the case of the severely anemic subjects the blood samples were first concentrated by removal of plasma under oil to bring the packed cell volume approximately to normal.

$$
\mathrm{pHc}=\mathrm{pK} \mathrm{c}+\log \frac{\left(\mathrm{BHCO}_{3}\right) \text { blood }}{\left(\mathrm{H}_{2} \mathrm{CO}_{3}\right) \text { blood }}
$$

where $\left(\mathrm{BHCO}_{3}\right)$ blood $=$ the total $\mathrm{CO}_{2}$ of oxygenated blood at $40 \mathrm{~mm}$. $\mathrm{Hg}$ partial pressure of $\mathrm{CO}_{2}$ and $\left(\mathrm{H}_{2} \mathrm{CO}_{8}\right)$ blood $=\mathrm{H}_{2} \mathrm{CO}_{3}$ content of blood calculated from the formula $\left(\mathrm{H}_{2} \mathrm{CO}_{8}\right)=\mathrm{a}\left(\mathrm{pCO}_{2}\right)$ where "a" is the solubility coefficient of carbon dioxide in blood (from data 


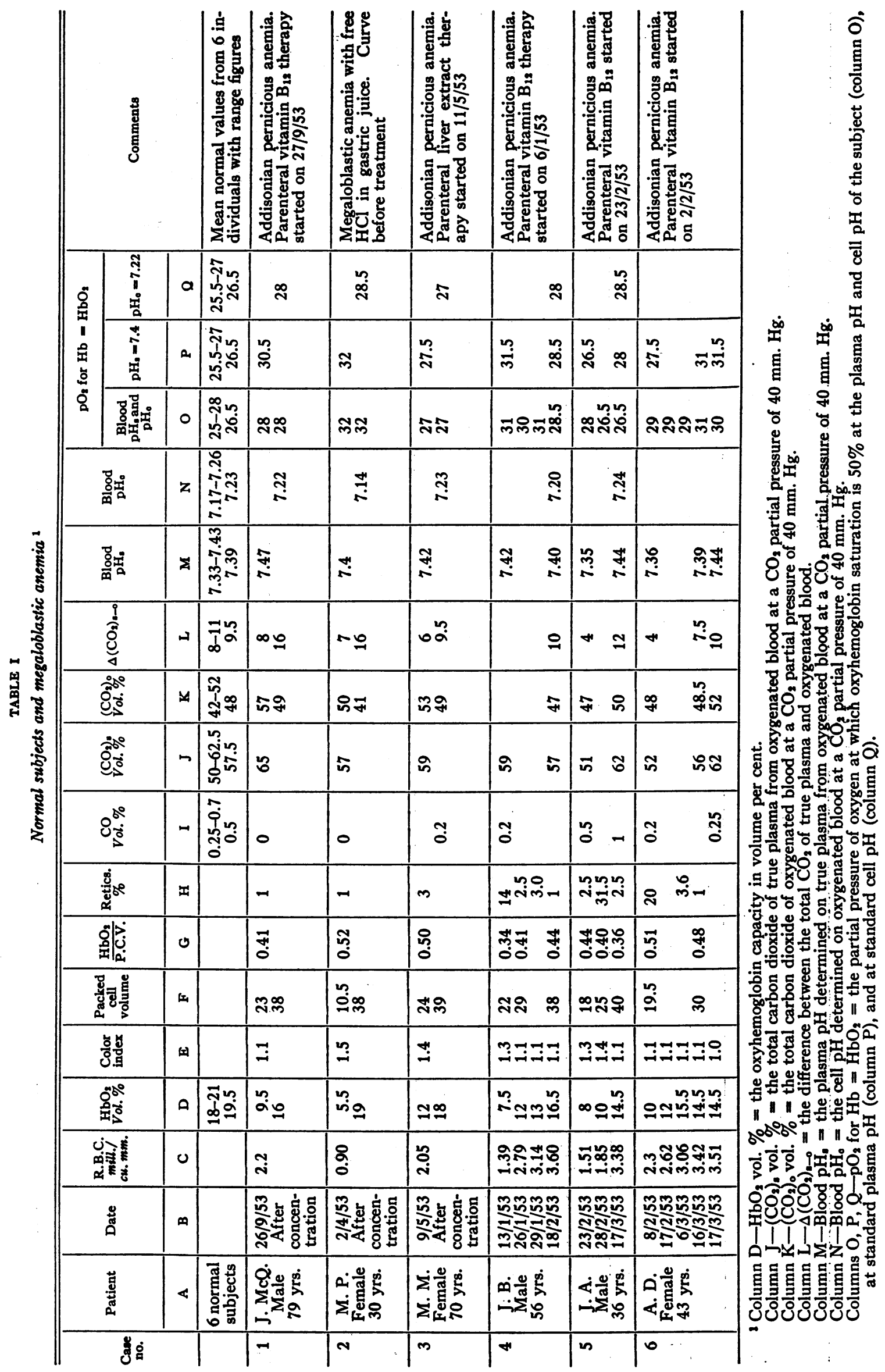




\begin{tabular}{|c|c|c|c|c|c|c|c|c|c|}
\hline $\begin{array}{l}\text { 量 } \\
\text { 量 }\end{array}$ & & 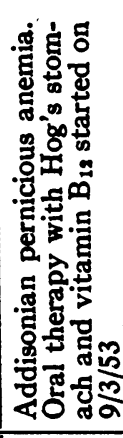 & 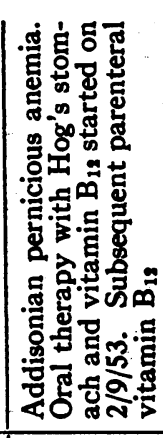 & 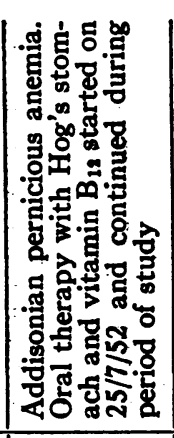 & 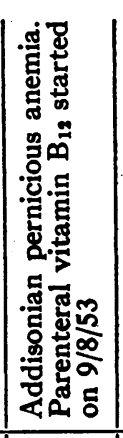 & 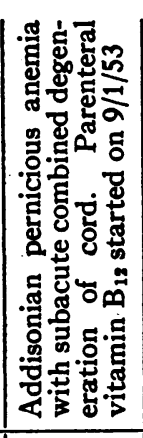 & 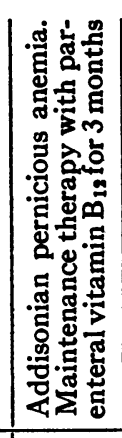 & 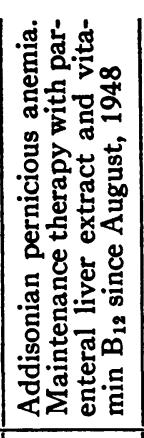 & 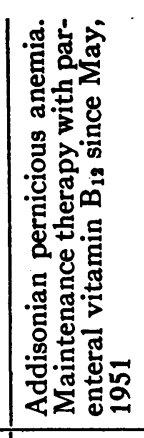 \\
\hline 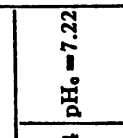 & $a$ & & & & & & a & 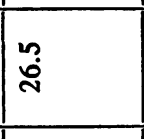 & \\
\hline 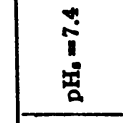 & 2 & 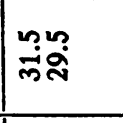 & $\mathbb{m} \quad$ A & $\therefore \stackrel{\leftrightarrow}{\infty}$ & 宓 & $\prod_{\substack{n \\
m}}$ & i & 赵 & \\
\hline 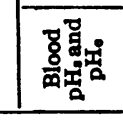 & 0 & চొని & 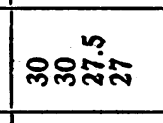 & 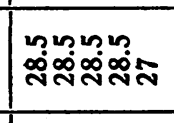 & $\mid$ & m. & i & a & i \\
\hline 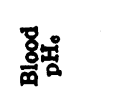 & $z$ & & & & & & สุ & דיָ & \\
\hline$\frac{\delta_{i}}{m}$ & $\nexists$ & 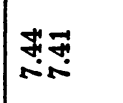 & 푼 윤 & 풍융 & 倠? & I: & 용 & 疍 & \\
\hline$\frac{?}{3}$ & $\rightarrow$ & $0 \%$ & $\stackrel{\Omega}{\wedge} \simeq$ & in $n$ & 100 & in & a & 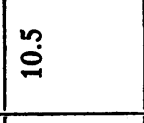 & \\
\hline $\begin{array}{l}30 \\
8 \% \\
08\end{array}$ & $\$$ & $n_{n \rightarrow \infty}$ & $\begin{array}{ll} \\
0 \\
\infty\end{array}$ & in & 冓央 & in & $\infty$ & 3 & \\
\hline की & - & ช\% & : in & in $\infty$ & ธ艹 & is & in & 每 & \\
\hline $88^{\circ}$ & - & 0 & $\dddot{8}$ & $\approx$ & 10 & $0 \stackrel{n}{0}$ & 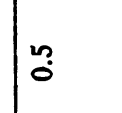 & 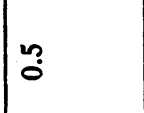 & 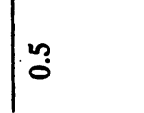 \\
\hline$\frac{\dot{s}}{\mathrm{~s}}$ & \pm & a & ins & 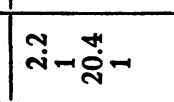 & $\mid-\stackrel{n}{-\infty}$ & 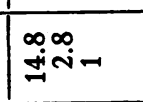 & - & & \\
\hline 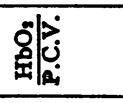 & 0 & 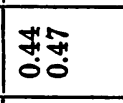 & 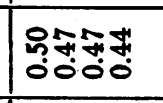 & 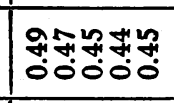 & 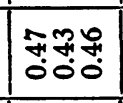 & S.7. & 遂 & J & i̊용 \\
\hline 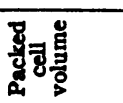 & 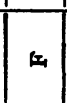 & $\because \infty$ & 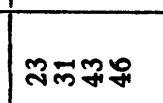 & |ำสพฺ์ & $\mid$ & 紫 & is & F & 8 \\
\hline 郭器 & $\infty$ & בִ & 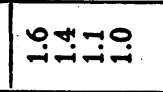 & ت־ & 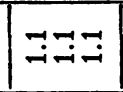 & 폭요 & $\equiv$ & 9 & i \\
\hline 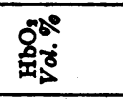 & 0 & $\begin{array}{l}202 \\
\infty \\
\infty\end{array}$ & 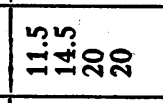 & 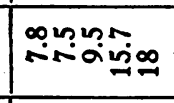 & : & 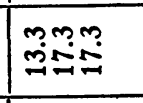 & $\infty$ & ח. & i \\
\hline 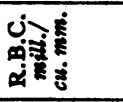 & 0 & F⿻ & Trofి & 7. & 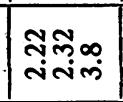 & 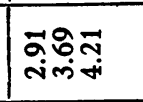 & $\exists$ & 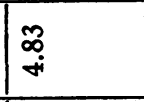 & 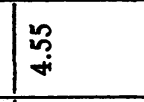 \\
\hline 高 & $\infty$ & 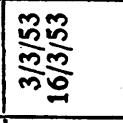 & 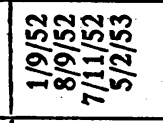 & 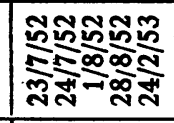 & 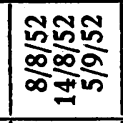 & 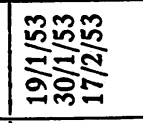 & $\begin{array}{l}\frac{0}{0} \\
\frac{m}{0} \\
0\end{array}$ & 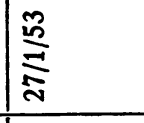 & 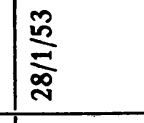 \\
\hline 喜 & 4 & 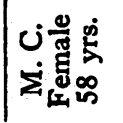 & 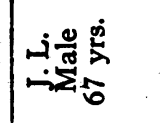 & 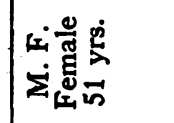 & 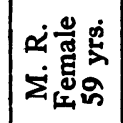 & 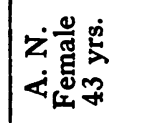 & $\mid$ & 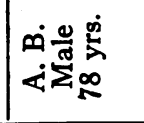 & 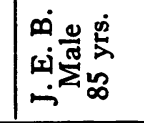 \\
\hline )ू̆ & & I & $\infty$ & a & o & $\Rightarrow$ & $\approx$ & $m$ & 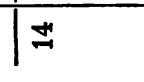 \\
\hline
\end{tabular}




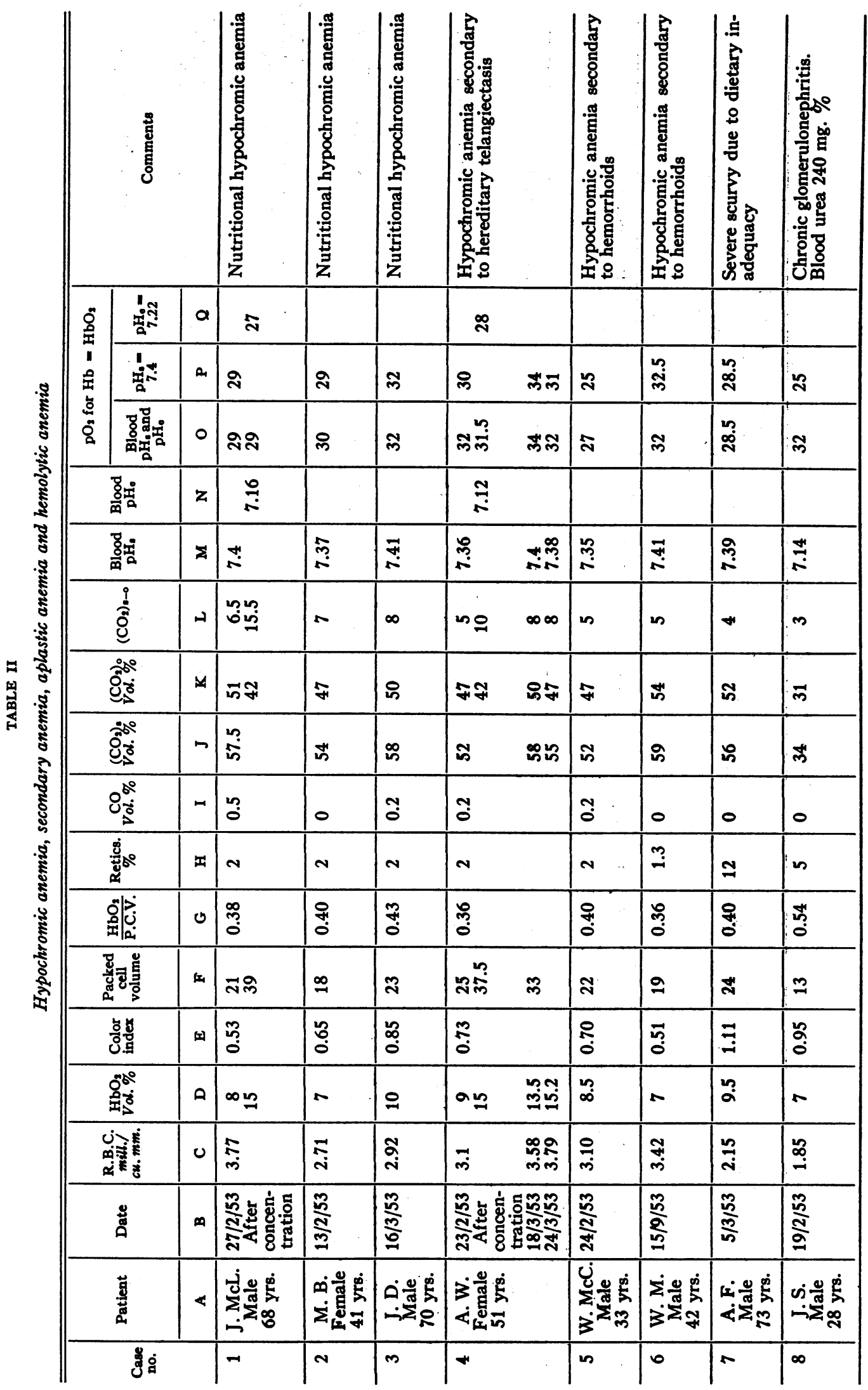




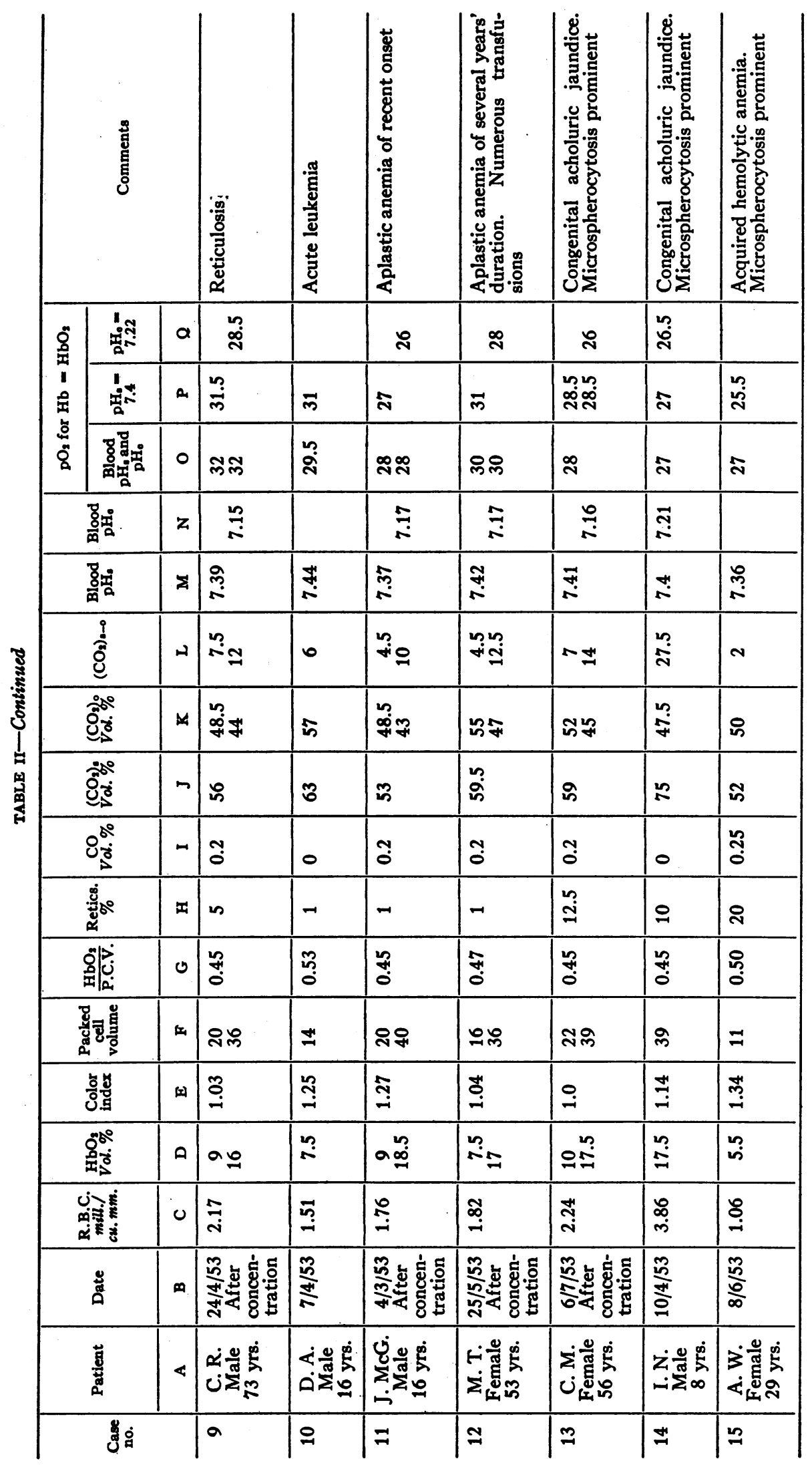


TABLE III

Oxyhemoglobin saturation of laked blood solutions derived from patients with anemia

\begin{tabular}{ccccc}
\hline \hline & $\begin{array}{c}\text { Pernicious } \\
\text { anemia in } \\
\text { relapee } \\
\text { (Table I, } \\
\text { Case 8) }\end{array}$ & $\begin{array}{c}\text { Hypo- } \\
\text { chromic } \\
\text { anemia } \\
\text { (Table II, } \\
\text { Case 4) }\end{array}$ & $\begin{array}{c}\text { Pernicious } \\
\text { anemia } \\
\text { after } \\
\text { treatment } \\
\text { (Table I, } \\
\text { Case 10) }\end{array}$ \\
\hline pO2 mm. Hg & & HbO2 Volume \% & \\
\hline 15 & 28 & 29 & 29 & 28 \\
20 & 50 & 50 & 48 & 50.5 \\
30 & 78 & 80 & 78 & 79 \\
40 & 86 & 87 & 85 & 85 \\
\hline
\end{tabular}

by Dill in the paper of Keys, Hall, and Barron (6) and Dill, Graybiel, Hurtado, and Taquini (7)).

$\mathrm{pK}^{\prime} \mathrm{c}$ was obtained from the alignment chart and procedure given in the paper of Keys, Hall, and Barron (6) modified in such a manner for the $\mathrm{pK}^{\prime} \mathrm{c}$ to be 5.98 for normal blood $(8,9)$ giving a cell $\mathrm{pH}$ of 7.20 to 7.25 . The other values for $\mathrm{pK}^{\prime} \mathrm{c}$ derived from this alignment chart were changed proportionately.

Correction of the position of the curve according to the plasma $\mathrm{pH}$ and cell $\mathrm{pH}$ was carried out in curves drawn on logarithmic co-ordinates by a slight modification (10) of the procedure outlined by Dill in the paper of Keys, Hall, and Barron (6).

Buffered solutions of laked blood of $\mathrm{pH} 7.4$ were prepared according to the methods described by Brooks (11) and Darling and Roughton (12).

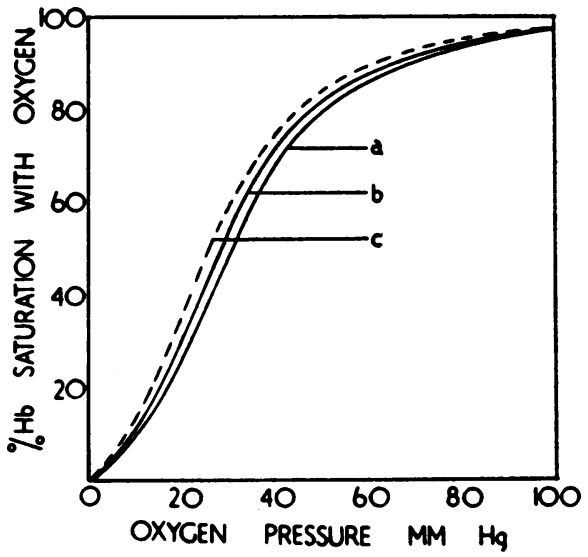

Fig. 1. Oxygen Dissociation Curves from Anemic aNd Normal SubJects

Curve a-Addisonian pernicious anemia in relapse, hypochromic anemia, secondary anemia. At serum $\mathrm{pH}$ 7.4

Curve b-Addisonian pernicious anemia in relapse, hypochromic anemia, secondary anemia. At cell pH 7.22

Curve c-Normal blood at serum $\mathrm{pH} 7.4$ and cell $\mathrm{pH}$ 7.22

\section{RESULTS}

The results are presented in Tables I, II, and III and in Figure 1. The position of the oxygen dissociation curve is indicated by the partial pressure of oxygen at which 50 per cent of the hemoglobin is oxygenated.

In Table I are shown the mean values obtained from six normal individuals, which have been presented in detail elsewhere (10), and the individual data of eleven patients with megaloblastic anemia in relapse and three in therapeutic remission. Of the patients in relapse the position of the oxygen dissociation curve at the plasma and cell $\mathrm{pH}$ of the subject (column $\mathrm{O}$ ) was displaced to the right of normal in all but one (case 3 ). After correction to the standard plasma $\mathrm{pH}$ of 7.4 (Column $\mathrm{P}$ and curve a of Figure 1) this shift to the right was more pronounced except in cases 5 and 6 . In these two cases the curve was nearly normal at standard plasma $\mathrm{pH}$. Serial observations (cases 4, 8-11) show that the displacement to the right of the oxygen dissociation curve did not alter during the earlier response to treatment, although by the time the red cell count had reached about the four million per cubic $\mathrm{mm}$. level, between four and six weeks, some lessening of the displacement was apparent. In the two patients in whom the initial oxygen dissociation curves were normal at standard plasma $\mathrm{pH}$ (cases 5 and 6) a shift to the right developed during the early stages of treatment. The presence of reticulocytes (column $\mathrm{H}$ ) did not appear to influence the position of the oxygen dissociation curve. The curve was normal in position in the three patients in therapeutic remission (cases 12-14). The cell $\mathrm{pH}$ (column $\mathrm{N}$ ) was determined in seven of the cases, of whom three were in relapse, two were during treatment, and two were in therapeutic remission. Of the cases in relapse, the difference between the cell and plasma $\mathrm{pH}$ was increased in those showing a shift of the oxygen dissociation curve to the right at standard plasma $\mathrm{pH}$ (cases 1 and 2), and normal in the case showing a normal oxygen dissociation curve at standard plasma $\mathrm{pH}$ (case 3 ). In the patients (cases 4 and 5 ) in whom the cell $\mathrm{pH}$ was determined when the red cell count had reached between three and four millions per cubic mm., at which time the oxygen dissociation curve was still slightly displaced to 
the right at standard plasma $\mathrm{pH}$, the difference between the cell and plasma $\mathrm{pH}$ was normal. After correction to standard cell $\mathrm{pH}$ the position of the oxygen dissociation curve was unaltered (column Q). The cell $\mathrm{pH}$ was normal in the two patients in therapeutic remission (cases 12 and 13) both of whom showed a normal position of the oxygen dissociation curve.

In Table II are shown the results obtained in patients with nutritional hypochromic anemia, chronic post-hemorrhagic anemia, secondary anemia, aplastic anemia, and hemolytic anemia. With the exception of the case of anemia associated with chronic nephritis (case 8), in which there was an acidosis, the plasma $\mathrm{pH}$ of the subjects was nor$\mathrm{mal}$; in the majority of cases the values were in the lower range of normal. The position of the oxygen dissociation curve at the plasma and cell $\mathrm{pH}$ of the subject was displaced to the right of normal in all the patients with the exception of one patient with post-hemorrhagic anemia (case 5), one patient with aplastic anemia (case 11), and all three patients with hemolytic anemia (cases 13-15). The displacement to the right was still present after correction to the standard plasma $\mathrm{pH}$ of 7.4 (Figure 1, curve a) excepting the patient with chronic nephritis whose curve was to the right of normal at blood plasma $\mathrm{pH}$ but normal in position at standard plasma $\mathrm{pH}$. The cell $\mathrm{pH}$ was low in six of the seven cases in which it was determined and normal in the remaining case (case 14), a patient with hemolytic anemia. After correction to the standard cell $\mathrm{pH}$ the position of the oxygen dissociation curve was normal in the two patients with hemolytic anemia (cases 13,14 ) and in one patient with aplastic anemia (case 11) but was still slightly to the right (Figure 1, curve b) in the patients with hypochromic anemia (cases 1,4 ), secondary anemia (case 9), and the remaining patient with aplastic anemia (case 12).

Table III shows that the oxygen dissociation curves of hemoglobin solutions (buffered solutions of laked blood) from patients with pernicious anemia and hypochromic anemia are the same as that of hemoglobin solutions of normal blood.

\section{DISCUSSION}

Odaira (1) states that in anemia there is a marked acidosis and that as a result there is a shift to the right of the oxygen dissociation curve.
The techniques employed by Odaira are open to criticism, however, and many authors $(3,4,13-$ 16) have failed to demonstrate an acidosis in pernicious anemia but have, in fact, shown a tendency to an alkalosis. Stadie and Martin (17), obtained a normal oxygen dissociation curve in a single patient with pernicious anemia but they do not give the plasma $\mathrm{pH}$ at which the curve was performed. Richards and Strauss (2) reported that the oxygen dissociation curves in six patients with pernicious anemia and five patients with secondary anemia were in the normal position at the normal plasma $\mathrm{pH}$ of the blood (7.4), and that only at the abnormal plasma $\mathrm{pH}$ of 7.64 was there a shift to the right. Several of the cases studied by Richards and Strauss had received transfusions of whole blood within a few days prior to the determination of the oxygen dissociation curves. In discussing the cause of the shift observed at plasma $\mathrm{pH} 7.64$, they suggest that it could be due, in the patients with pernicious anemia, to an increased concentration of hemoglobin within the red cell, which would have the result, at this high plasma $\mathrm{pH}$, of increasing the value $(-\log \mathrm{r})$ as developed by Van Slyke, Wu, and McLean (18, 19) and so increasing the difference between the plasma and cell $\mathrm{pH}$. The hypothesis is admitted to be invalid in hypochromic anemia in which there is a shift of the oxygen dissociation curve to the right. Dill and his co-workers (3) report that in one patient with pernicious anemia the oxygen dissociation curve performed before treatment was normal but the subsequent curves during treatment with liver orally, and single curves in four other cases of pernicious anemia during treatment, were displaced to the right of normal. No curves were determined after recovery from anemia. Dill and his co-workers by indirect methods found the value $\mathrm{rH}$ to be smaller than normal and so conclude that the difference between plasma and cell $\mathrm{pH}$ is increased, the cell $\mathrm{pH}$ being relatively more acid than normal. Both Dill and his co-workers and Henderson (20) were unable to relate the observed shift in the oxygen dissociation curve to altered osmotic or electrolytic relationships between cell and plasma. Isac, Matthes, and Yamanaka (4) found that the oxygen dissociation curves in four patients with pernicious anemia, four patients with secondary anemia, one patient with aplastic anemia, and one patient with hemolytic 
anemia were displaced to the right of normal. These authors, using indirect methods like Dill and his co-workers, were unable to demonstrate any decrease in the cell $\mathrm{pH}$.

The present observations confirm that there is a shift to the right of the oxygen dissociation curve at standard plasma $\mathrm{pH}$ in the majority of patients with hypochromic anemia, secondary anemia, and megaloblastic anemia in relapse, thus providing for the anemic patient an increased yield of oxygen to the tissues. The time taken for the shift in the curve to lessen following treatment was in the patients with megaloblastic anemia some four to six weeks but it should be noted that many of these patients were the subjects of an investigation of the value of oral vitamin $B_{12}$ in the therapy of pernicious anemia and were not always showing optimal hematological responses. It is not apparent why two of the patients with megaloblastic anemia had a normal oxygen dissociation curve initially but developed a shift to the right during the course of treatment. A similar development was observed by Dill and his co-workers. The present investigation does not confirm that there is a shift to the right of the oxygen dissociation curve in hemolytic anemia (4).

The beneficial effect of the displacement of the oxygen dissociation curve is obvious but the mechanism responsible for it is not apparent. A reduction of the plasma $\mathrm{pH}$ of the subject would displace the curve to the right but there is no evidence that acidosis is present and moreover the displacement of the curve is still present after correction to standard plasma $\mathrm{pH}$. The presence of carboxyhemoglobin causes a shift to the left of the oxygen dissociation curve (17) and the position of the oxygen dissociation curve in the normal subject may be influenced to a small extent by the carboxyhemoglobin present (21). We have found smaller amounts of carboxyhemoglobin in the anemic subjects than in normal subjects but the quantities involved are so small that they could not produce the observed displacement of the oxygen dissociation curve. Alteration in the concentration of hemoglobin within the red cell also cannot be the factor responsible for the displacement of the oxygen dissociation curve since the displacement is demonstrable in both pernicious anemia and hemoglobin deficiency anemia. The effect of the increased plasma volume in anemia can likewise be excluded as the cause of the displacement since artificial dilution with fresh plasma from the same individual does not influence the position of the oxygen dissociation curve $(2,5)$.

It is now accepted $(22,23)$ that many different kinds of hemoglobin, at least some of which may influence the position of the oxygen dissociation curve, may be present in pathological states. It is unlikely, however, that an abnormality of hemoglobin can be responsible for the observed displacement of the oxygen dissociation curve in anemia since the oxygen dissociation curves of hemoglobin solutions of anemic blood are the same as those of normal blood.

The position of the oxygen dissociation curve is dependent basically upon the cell $\mathrm{pH}$ and it is unfortunate that there is no entirely satisfactory method by which the cell $\mathrm{pH}$ can be determined directly. Hampson and Maizels (24) using a direct method at room temperature (glass electrode determinations on red cells hemolysed by repeated exposure to low temperature) found that the difference between the cell $\mathrm{pH}$ and plasma $\mathrm{pH}$ in pernicious anemia was greater than normal while in hypochromic anemia it was less than normal. Maizels (25), in referring to cell $\mathrm{pH}$ determinations, expresses doubts about his results partly because of the many manipulations involved and partly because the determinations were made at room temperature in conditions far removed from those in which red cells exist in the body. The indirect method for determining cell $\mathrm{pH}$, in which the value " $r$ " as developed by Van Slyke, $W u$, and McLean (18) $\left(-\log \mathrm{r}=\mathrm{pH}_{\mathrm{s}}-\mathrm{PH}_{\mathrm{c}}\right)$ is determined, or the nomogram developed by Dill (see 6) is used, is superior to the direct method particularly as regards comparative studies, although the Henderson-Hasselbalch equation is not a strict physical chemical equation. If the indirect method, however, is applied to anemic blood where the cell phase is small, there is the disadvantage that experimental errors are multiplied. To avoid this disadvantage the cell $\mathrm{pH}$ was determined after concentrating the anemic blood samples by removal of plasma under oil to bring the packed cell volume into the normal range. This manipulation permits more accurate study.

Using this indirect method the cell $\mathrm{pH}$ was low relative to the plasma $\mathrm{pH}$ in cases of pernicious anemia in relapse and cases of hypochromic anemia 
which showed a displacement of the oxygen dissociation curve to the right. On the other hand, in cases of pernicious anemia in therapeutic remission having the oxygen dissociation curve normal in position, the cell $\mathrm{pH}$ was normal. The cell $\mathrm{pH}$ was also normal in the case of pernicious anemia in relapse which showed a normal oxygen dissociation curve. In the cases in which the cell $\mathrm{pH}$ was low correction of the oxygen dissociation curve to the standard cell $\mathrm{pH}$ largely, but not completely, corrected the displacement to the right, suggesting that while a low cell $\mathrm{pH}$ is the main factor in producing the displacement there is also a further factor. In both cases of aplastic anemia the cell $\mathrm{pH}$ was also found to be low. Correction of the position of the oxygen dissociation curve in these cases to the standard cell $\mathrm{pH}$ wholly eliminated the displacement of the curve in the case of recent onset and partly corrected it in the case of longstanding. This patient had received numerous blood transfusions over several years and it would be unwise to draw any conclusions from examining this individual's oxygen dissociation curve since it would appear that one was in fact examining the oxygen dissociation curve of many donors. The cell $\mathrm{pH}$ was low in one of the two cases of hemolytic anemia in which the cell $\mathrm{pH}$ was determined and normal in the other. In the former case, correction of the position of the curve to the standard cell $\mathrm{pH}$ wholly corrected the slight displacement of the oxygen dissociation curve that was present at the cell $\mathrm{pH}$ of the subject. The cases of pernicious anemia studied during recovery showed that the oxygen dissociation curve is still slightly abnormal when the red cell count is about the 4 million per cubic $\mathrm{mm}$. level, at which time there is still a degree of macrocytosis. In the cases in complete therapeutic remission, where there is no macrocytosis, there is no displacement of the oxygen dissociation curve.

While a lowered cell $\mathrm{pH}$ thus accounts for the major part of the displacement of the oxygen dissociation curve the results suggest that there is in addition a further factor. Measurements of the red cell diameter thickness ratio were not made in this study but the observed relationship between displacement of the oxygen dissociation curve and shape of the red cell in stored red blood cells (5, $10)$ indicates that such measurements might use- fully be done in further studies in gas transport in anemia.

\section{SUMMARY}

1. The oxygen dissociation curves in twentynine cases of anemia have been studied.

2. In ten of the eleven cases of megaloblastic anemia in relapse and in nine of the ten cases of hypochromic anemia and secondary anemia there was a slight displacement of the oxygen dissociation curve to the right. No shift to the right was present in three cases of hemolytic anemia or in one of two cases of aplastic anemia.

3. The displacement of the oxygen dissociation curve persisted during the period of recovery in the cases of megaloblastic anemia but was not present in cases in therapeutic remission. The position of the curve was not influenced by the presence of reticulocytes.

4. The major part of the displacement appears to be due to an alteration in the cell $\mathrm{pH}$.

\section{ACKNOWLEDGMENT}

The authors wish to express their gratitude to Professor L. J. Davis for his advice throughout this study.

\section{REFERENCES}

1. Odaira, R., The change in the reserve alkali and oxygen dissociation curve of blood in clinical and experimental anemias. Tohoku J. Exper. Med., 1923, 4, 243.

2. Richards, D. W., Jr., and Strauss, M. L., Oxy-hemoglobin dissociation curves of whole blood in anemia. J. Clin. Invest., 1927, 4, 105.

3. Dill, D. B., Bock, A. V., Van Caulaert, C., Fölling, A, Hurxthal, L. M., and Henderson, L. J., Blood as a physicochemical system. VII. The composition and respiratory exchanges of human blood during recovery from pernicious anemia. J. Biol. Chem., 1928, 78, 191.

4. Isac, C., Matthes, K., and Yamanaka, T., Untersuchungen über den Transport des Sauerstoffs im menschlichen Blut; der Sauerstofftransport im Blute bei verschiedenen Krankheiten. Arch. f. exper. Path. u. Pharmakol., 1938, 189, 615.

5. Valtis, D. J., and Kennedy, A. C., Defective gastransport function of stored red blood-cells. Lancet, 1954, i, 119.

6. Keys, A., Hall, F. G., and Barron, E. S. G., The position of the oxygen dissociation curve of human blood at high altitude. Am. J. Physiol., 1936, 115, 292. 
7. Dill, D. B., Graybiel, A., Hurtado, A., and Taquini, A. C., Der Gasaustausch in den Lungen im Alter. Ztschr. f. Altesfoschung, 1940, 2, 20.

8. Dill, D. B., Daly, C., and Forbes, W. H., The pK' of serum and red cells. J. Biol. Chem., 1937, 117, 569.

9. Dill, D. B., Edwards, H. T., and Consolazio, W. V., Blood as a physicochemical system. XI. Man at rest. J. Biol. Chem., 1937, 118, 635.

10. Valtis, D. J., and Kennedy, A. C., The causes and prevention of defective function of stored red blood cells after transfusion. Glasgow M. J., 1953, 34, 521.

11. Brooks, J., The oxidation of haemoglobin to methaemoglobin by oxygen. II. The relation between the rate of oxidation and the partial pressure of oxygen. Proc. Roy. Soc., 1935, 118, 560.

12. Darling, R. C., and Roughton, F. J. W., The effect of methemoglobin on the equilibrium between oxygen and hemoglobin. Am. J. Physiol., 1942, 137, 56.

13. Barr, D. P., and Peters, J. P., Jr., III., The carbon dioxide absorption curve and carbon dioxide tension of the blood in severe anemia. J. Biol. Chem., 1921, 45, 571.

14. Dautrebande, L., L'alcalose paradoxale de l'anémie pernicieuse. Compt. rend. Soc. de biol., 1925, 93, 1031.

15. Connery, J. E., and Jolliffe, N., Studies on the "acid deficit" in pernicious anemia, with report of a case showing return of free acid. Am. J. M. Sc., 1931, 181,830 .

16. Emerson, C. P., Jr., and Helmer, O. M., Reaction $(\mathrm{pH})$ and carbon dioxide content of the venous plasma in pernicious anemia. Arch. Int. Med., 1935, 55, 254.
17. Stadie, W. C., and Martin, K. A., The elimination of carbon monoxide from the blood. J. Clin. Invest., 1925, $2,77$.

18. Van Slyke, D. D., Wu, H., and McLean, F. C., Studies of gas and electrolyte equilibria in the blood. V. Factors controlling the electrolyte and water distribution in the blood. J. Biol. Chem., 1923, 56, 765.

19. Van Slyke, D. D., Factors Affecting the Distribution of Electrolytes, Water and Gases in the Animal Body; Lectures, Delivered at Rutgers University under the Luther Laflin Kellogg Foundation. Philadelphia, J. B. Lippincott, 1926, 62 p.

20. Henderson, L. J., Blood; A Study in General Physiology. New Haven, Yale University Press, 1928, $397 \mathrm{p}$.

21. Riley, R. L., Lilienthal, J. L., Jr., Proemmel, D. D., and Franke, R. E., The relationships of oxygen, carbon dioxide, and hemoglobin in the blood of man: Oxyhemoglobin dissociation under various physiological conditions. J. Clin. Invest., 1946, 25, 139.

22. Darling, R. C., Smith, C. A., Asmussen, E., and Cohen, F. M., Some properties of human fetal and maternal blood. J. Clin. Invest., 1941, 20, 739.

23. Eastman, N. J., Geiling, E. M. K., and De Lawder, A. M., Fetal blood studies. IV. The oxygen and carbon-dioxide dissociation curves of fetal blood. Bull. Johns Hopkins Hosp., 1933, 53, 246.

24. Hampson, A. C., and Maizels, M., The difference of pH between plasma and red cells. J. Physiol, 1927-28, 64, XX.

25. Maizels, M., Phosphate, base and hemolysis in stored blood. Quart. J. Exper. Physiol., 1943, 32, 143. 